\title{
Theoretical Basements for a Clinical Trial on COVID-19 Patients with Systemic Ozone Therapy
}

\author{
Francisco Javier Hidalgo Tallón ${ }^{1,4 *}$, Silvia Menendez-Cepero ${ }^{2}$, José Baeza-Noci ${ }^{3}$ and Gonzalo Gea Carrasco ${ }^{5}$ \\ ${ }^{1}$ Institute of Neuroscience, University of Granada, Spain \\ ${ }^{2}$ Scientific Advisor, 1350 Asturia Ave. Coral Gables, 33134-Florida, USA \\ ${ }^{3}$ School of Medicine and Surgery, University of Valencia, Spain \\ ${ }^{4}$ Department of Ozone Therapy and Chronic Pain, Catholic University San Antonio of Murcia (UCAM), Spain \\ ${ }^{5}$ Catholic University San Antonio of Murcia (UCAM), Spain
}

${ }^{*}$ Corresponding author: Francisco Javier Hidalgo Tallón, Institute of Neuroscience, University of Granada, and Department of Ozone Therapy and Chronic Pain, Catholic University San Antonio of Murcia (UCAM), Spain; E-mail: fjht63@gmail.com

Received: January 12, 2021; Accepted: January 21, 2021; Published: February 12, 2021

\begin{abstract}
Systemic ozone treatment has proved, in different clinical studies, to enhance exchange of gases and blood circulation, improve lung function in chronic pulmonary diseases, reduce viral load in patients infected by Herpes virus, Hepatitis B and C virus, Human Immunodeficiency virus and reduce significantly IL-6 and other proinflammatory cytokines in chronic inflammation diseases. All these results support the rationale to set up a clinical trial for patients suffering COVID-19 as an adjuvant treatment until we found an eventual cure.
\end{abstract}

Keywords: COVID-19, Ozone therapy, SARSCoV2, Systemic ozone treatment

\section{Proposed Hypothesis}

Due to the extreme world situation caused by COVID19 pandemic we consider unethic not to try any treatment option with a justified rationale. We have explained that medical ozone therapy has a clear scientific basement thanks to all preclinical investigation already published. It can be classified as chemical stressor that produces a modulation of the redox balance and immunity. Moreover, it is easy and safe to administer [1]. The efficacy in viral diseases have been published together the modulation of IL-6 and other proinflammatory cytokines that could potentially help in COVID19 patients. We proposed to carry out a randomized control trial to evaluate the safety and efficacy of systemic ozone (indirect endovenous and rectal) in these patients.

\section{Introduction}

\section{Coronavirus}

The new Severe Acute Respiratory Syndrome (SARS) produced by the new coronavirus, SarsCoV2, has been expanding since past December and declared by WHO as pandemic. Today (March, 27th, 2020) there are 465915 confirmed patients and in Spain the number of cases is 65719 [2]. Mortality rate is around $3.7 \%$ and there is no proved treatment [3]. From a clinical point of view, it produces an acute respiratory distress with hemophagocytic lymphohystiocytosis that induces a fatal increase of blood cytokines. The patients also show increased ferritin, interleukyne 6 (IL-) and decrease of platelets as markers of a starting huge inflammation process that can lead to heart failure [4]. In severe ill patients, we found increased prothrombin time, partial thromboplastin time, D-dimer, lactatedehydrogenase, procalcitonine, albumin, C-reactive protein and aspartate aminotransferase [5].

\section{Medical Ozone Therapy}

Medical ozone is a mixture of ozone and medical oxygen produced by a trustable and accurate medical device. Ozone therapy is the use of medical ozone, a safe therapeutic agent, to treat pain and other diseases. Due to the growing interest on these techniques, the World Federation of Ozone Therapy - WFOT published in 2015 a scientific review devoted to health professionals interested in knowing and understanding the biochemistry, pharmacology and indications of medical ozone [6].

\section{Ozone Germicidal Effect}

Ozone has proved its efficacy against virus, bacteria (gram positive as well as gram negative), fungus and spores. This is due to its high oxidant capacity that cannot be handled by the classical microbial resistance mechanisms and damages the microbial membranes irretrievably [7]. Its effect is universal but selective. Universal, because it is effective in all microbes, even for Pseudomonas aeruginosa and Escherichia coli, both with a high antibiotic resistance. Selective, because it respects eukaryot healthy cells, due to the huge antioxidant capability of them and their environment. We can find papers about this effect on MS2 bacteriophage virus, Norwalk Virus, poliovirus 1, hepatitis A and Coxsackievirus [8-11]. 
The inner mechanism of germicidal effect is due to:

- Double bounds in polyunsaturated fatty acids (PUFA) of the membrane being broken by ozone.

- Amino acids (cysteine, methioine, histidine) reacting with ozone in their thiols groups.

Over viruses, apart from the membrane damage, lipid peroxides from the membrane reaction interfere the reverse transcriptase, basic for the virus replication [12]. This antimicrobial effect has nothing to do with the in vivo mechanisms of action that contribute to the infection cure and that could be useful for COVID-19 patients.

\section{Biological Effects of Medical Ozone}

The administration of medical ozone in order to protect and repair organic damage has demonstrated to be an effective and safer stress than the ischemic one. Ozone has proved to be effective against hepatic damage induced by ischemia/reperfusion [13-17], partial hepatectomy [18] or toxicity by carbon tetrachloride [19] or methotrexate [20]. It has also been proved that ozone enhances the ketamine hepatoprotection in septic rats [21]. Similar findings have been reported for renal damage in ischemia/reperfusion models [2228], toxicity due to radiological contrast [29], adriamicine [30], partial nephrectomy [31], diabetes [32] or methotrexate [33]

Also, in heart and skeletal muscle damage due to ischemia/ reperfusion or toxicity by doxorubicin [34-38]. Intestinal damage induced by methotrexate [39], lung irradiation damage [40], fecal peritonitis [41] and endotoxic shock [42]. From these papers about ozone oxidative preconditioning, we know the biological mechanisms underneath the tissue restoration induced by the ozone mild controlled oxidative process. The biochemical reaction of medical ozone on the PUFA transported by albumin generates (Criegee's reaction) alpha-hydroxy-hydroperoxydes, hydrogen peroxide, and aldehydes, like 4-hydroxynonenal. These last are well known signaling molecules modulating inflammation, proliferation, growing and cellular death (necrotic or apoptotic) [43,44].

The mild acute oxidative stress induced by ozone also modulates the activation of different nuclear transcription factors (NF) [45]: Nuclear Factor of Activated T-cells and Activated Protein-1, Goth related with immunity, Hypoxia Inducible Factor-1a, related with vascular degeneration and NRF2 (Nuclear factor Erythroid-2-Related Factor-2), that regulates the synthesis of mediators of inflammation and antioxidant enzymes (SOD, GPx, GSTr, CAT, HO-1, NQO-1, NADPH). Also modulates the release of heat shock proteins (HSP) that have a protective effect [46] especially in oncological $[47,48]$ and infectious diseases [49]. Pecorelli and Bocci checked an increase of NRF2 in plasma from healthy volunteers after ozone administration to cell cultures. The increase was dose related with a positive increase as ozone dose increased from 20 to $80 \mu \mathrm{g} / \mathrm{mL}$ [50,51]. Similar results were published by Re and cols. that also observed an increase in several heat shock proteins: HSP-60, HSP-70 y HSP-90 [52]. Related with this NRF2 modulation, a decrease in proinflammatory cytokines in multiple sclerosis patients has been published [53].

In erythrocytes, mainly through hydrogen peroxide that accelerates intra erythrocytes glycolysis and so, produces more ATP and an increase of 2,3-DPG, two changes are induced that help to improve blood circulation:

1. The increase of 2,3-DPG produces a shift to the right in the oxygen/hemoglobin dissociation's curve (Bohr effect) [54]. There is an increase in the exchange of gases in lungs and peripheral tissues because of this.

2. Improvement of the $\mathrm{Na} / \mathrm{K} 2+$ membrane pump, ATP dependent, that restores the membrane function usually affected in chronic illness [55]. This effect improves the blood rheology and microcirculation.

Moreover, ozone lipid peroxides induce the release of endothelial nitric oxide and nitrosotyhyols [56] that induce local and remote vase dilatation, antithrombosis and regulation of heart contractility $[57,58]$.

All these effects produce a great improvement of peripheral tissues oxygenation [59].

\section{Clinical Studies}

Clinical applications of medical ozone started at the beginning of the last century. In 1911 Dr. Noble Eberhart, chief of the department of physiology in University of Loyola (Chicago, Illinois, USA) published the book "A Working Manual of High Frequency Currents" that promotes the use of medical ozone for TBC, anemia, asthma, bronchitis, diabetes and others [60]. Today, in PubMed we can find more than 3000 papers on ozone therapy and more than 1200 are clinical studies [61]. Medical ozone therapy is used in Pain Medicine since 80 s $[62,63]$ having presently the highest level of evidence for specific indications; also, some dental applications have also a high level of evidence, mainly due the germicidal effect already commented.

\section{Cardio and Cerebrovascular Diseases}

The generic improvement of the blood circulation caused by medical ozone and the specific effect on the atheromatous plaque will be especially useful for this kind of diseases [64-66]. Giunta and cols. checked that 27 patients suffering of peripheral occlusive arterial disease treated with systemic medical ozone improved, not also the antioxidant capability but also the blood's perfusion and viscosity, hematocrit and fibrinogen, with no side effect [67]. A Cuban study recruited 120 patients with risks factors for heart attack and randomized them in 2 groups: control and treatment (ozone rectal insufflation). During one year, each 3 months, several clinical and biochemical parameters were registered. Ozone group was quite more stable both clinical and biologically. No side effects were found [68]. Other Cuban team treated 22 patients post heart attack with systemic indirect endovenous ozone application daily for 3 weeks and showed an improvement in the lipid metabolism and antioxidant capability. No side effects were detected [69]. The same team treated 120 patients with acute, subacute and chronic cerebrovascular disease. After 20 applications of rectal ozone, $86 \%$ of the patients improved clinically, specially the acute ones [70].

\section{Neumology}

A published clinical trial proved the efficacy of systemic ozone at different doses and ways of administrations in asthmatic patients. Improved in Ig $\mathrm{E}$ and antioxidant status together a decrease in 
inflammation markers. Indirect endovenous ozone was more effective at the same dose [71]. These findings were also found in a group of patients with emphysema treated with 2 cycles of 20 applications of rectal ozone insufflation. They found no side effect [72]. Borrelli and Bocci randomized 50 patients suffering chronic obstructive pulmonay disease in 2 groups: control and treatment with systemic indirect endovenous ozone. There found no improvement in basal oxygenation or lung function but they found improvement in effort tests: 6MWT, Borg dyspnoea scale, SGRQ, concentration and memory capability. No side effects were observed [73].

\section{Immunomodulation}

In 1990, Bocci and Paulesu studied the in vitro effects of ozone on human blood's leukocytes in concentrations from 2.2 and $108 \mathrm{mcg} /$ $\mathrm{mL}$ for 30 seconds. These authors found that concentrations around $42 \mathrm{mcg} / \mathrm{mL}$ were optimal for increasing interferon [74]. Years later, another in vitro studies showed that $40 \mathrm{mcg} / \mathrm{mL}$ produced optimal modulation on NFK $\beta$ and pro inflammatory cytokines without any side effect $[75,76]$. Primary IgA deficiency patients found more improvement with systemic ozone that with Transfer Factor 1 [77]. In secondary immunodeficiency pediatric patients treated with systemic ozone also improved clinically with a decrease in the infection rate and without side effects [78].

\section{Chronic Inflammation and Autoimmune Diseases}

Medical ozone has shown efficacy and safety in the treatment of chronic inflammatory intestinal diseases $[79,80]$ and rheumatoid arthritis $[81,82]$. All parameters improved in the groups treated also with systemic ozone.

Clinical trials have validated a decrease in IL-6 and other proinflammatory cytokines in diabetes mellitus [83], multiple sclerosis [53] and lumbar disc herniation patients [84]. This decrease was correlated with a clinical improvement and a stabilization in the course of the diseases.

\section{Viral Infections}

Herpes Virus. Medical ozone has found to be effective for herpes virus through local injections, topical ozonized oil and water and also in systemic administration. In postherpetic neuralgia, clinical enhancement has been detected through clinical studies with control groups using injected ozone around the dorsal root ganglium alone [85], combined with pregabaline [86] or with retrovirals and acupuncture [87] and epidural injected [88]. Also, ozone injections have been tested with and without pulsed radiofrequency showing the superiority of combining both treatments [89]. Trigeminal postherpetic neuralgia also improved with local injections of ozone around Gasser ganglium [90]. In mouth pathology, ozonized oil has found to be useful for cold sores [91]. Other studies have been published about topical ozonized oil and water in cutaneous herpetic neuralgia with positive results $[92,93]$.

Systemic ozone has proved to reduce significantly viral load in Herpes 1, 2 and Citomegalovirus [94]. Other controlled trials showed improvement not only for viral load but also for pain and quality of life. No side effects were found [95].
HIV. Based on in vitro preclinical studies [96] some authors have proposed and tried the efficacy and safety of systemic ozone in HIV. Bocci tested indirect endovenous approach [97] in 12 patients; after 7 months with 50 applications for patient and no side effect, he found no change in viral load [98]. Garber did 2 clinical studies (phase I and II) using indirect endovenous ozone in $10 \mathrm{HIV}$ patients. Ozone therapy was well tolerated but did not improve either any analytic parameter; although some clinical improvement was found for concomitant pathologies [99]. We want to mention Carpendale publication that obtained good results in reducing the diarrhea of these patients with rectal ozone insufflations [100]. Recently, Cespedes and cols. have published good results with a significant decrease of viral load and increase in CD4 and CD8 in 32 patients with 15 applications of systemic indirect endovenous ozone. No side effects were reported and quality of life improved [101].

Viral Hepatitis. Both, systemic indirect endovenous or rectal insufflation application of ozone have found to be effective. In 2009, Neronov published his experience on chronic B hepatitis. He concluded that there was an improvement in clinical and biochemical parameters and a decrease in gallstone rate [102]. These results were confirmed later by Chemishev [103]. A randomized control trial was published in 2008 treating 40 hepatitis B patients with conventional treatment and 20 of them also with systemic endovenous ozone. The improvement was significantly greater in the ozone group [104]. Last study on hepatitis B showed that 28 patients with clinical stability under retroviral treatments were submitted for systemic indirect endovenous ozone treatment. After 15 applications, HBs Ag and viral load decreased [105]. For hepatitis C, a similar study was done founding a greater decrease in ALT, AST and viral load; the decrease was proportional to the number of applications [106].

$\mathrm{Gu}$ and cols studied patients with severe chronic hepatitis $\mathrm{C}$ and renal failure. The randomized trial showed an improvement in liver and renal function with also an increase survival rate in the systemic ozone group [107].

\section{Safety of Medical Ozone Therapy}

Medical ozone therapy, properly applied, has been found safe thanks to all preclinical toxicological test performed according to Food and Drug Administration (FDA), World Health Organization and Cuban Regulatory Agency rules [108]. Acute and chronic toxicological tests have been carried out for rectal and intraperitoneal administrations. No adverse reaction was related to ozone. For rectal insufflation, also irritation test was performed with no side effect registered neither in acute or chronic administration.

The safety of ozone on blood was thoroughly studied by Bocci and cols [57]. Moreover, no adverse reaction was found for mutagenic, carcinogenic and teratogenic tests, in vitro and in vivo. However, ozone breathing was found to be extremely toxic, due to the minimal antioxidant capability of the alveolar fluid [109].

\section{References}

1. Bocci V, Zanardi L, Michaeli D, Travagli V (2009) Mechanisms of action and chemical-biological interactions between ozone and body compartments: A critical appraisal of the different administration routes. Curr Drug Ther 4: 159-173. 
2. MSCBS. Ministerio de Sanidad, Consumo y Bienestar Social - Professionals Situación actual Coronavirus.

3. WHO. Coronavirus disease 2019 (COVID-19) situation report -52.

4. Mehta P, McAuley DF, Brown M, Sanchez E, Tattersall RS, et al. (2020) COVID-19: consider cytokine storm syndromes and immunosuppression. Lancet 395: 1033-1034 [crossref]

5. Wan S, Xiang Y, Fang W, Zheng Y, Li B, et al. (2020) Clinical Features and Treatment of COVID- 19 Patients in Northeast Chongqing. J Med Virol 92: 797-806 [crossref]

6. Baeza-Noci J, Cabo-Soler JR, Moraleda-Gómez M, Menéndez-cepero S, Re L. Revisión WFOT sobre Ozonoterapia Basada en Evidencias. World Federation of Ozone Therapy - WFOT. Bolonia: WFOT

7. Razumovskii SD, Zaikov GE (1984) Ozone and its reactions with organic compounds. New York: Elsevier.

8. Kekez MM, Sattar SA (1997) A new ozone-based method for virus inactivation: preliminary study. Phys Med Biol 42: 2027-2039. [crossref]

9. Shin GA, Sobsey MD (2003) Reduction of Norwalk virus, poliovirus 1, and bacteriophage MS2 by ozone disinfection of water. Appl Environ Microbiol 69: 39753978. [crossref]

10. Herbold K, Flehmig B, Botzenhart K (1989) Comparison of ozone inactivation, in flowing water, of hepatitis A virus, poliovirus 1, and indicator organisms. Appl Environ Microbiol 55: 2949-2953. [crossref]

11. Emerson MA, Sproul OJ, Buck CE (1982) Ozone inactivation of cell-associated viruses. Appl Environ Microbiol 43: 603-608.

12. Gupta G, Mansi B (2012) Ozone therapy in periodontics. J Med Life 5: 59-67.

13. Peralta C, Xaus C, Bartrons R, León OS, Gelpi E, et al. (2000) Effect of ozone treatment on reactive oxygen species and adenosine production during hepatic ischemia- reperfusion. Free Rad Res 33: 595-605. [crossref]

14. Ajamieh HH, Menéndez S, Martínez-Sánchez G, Candelario-Jalil E, Re L, et al. (2004) Effects of ozone oxidative preconditioning on nitric oxide generation and cellular redox balance in a rat model of hepatic ischaemia-reperfusion. Liver Int 24: 55-62. [crossref]

15. Ajamieh HH, Berlanga J, Merino N, Sánchez GM, Carmona AM, et al. (2005) Role of protein synthesis in the protection conferred by ozone oxidative- preconditioning in hepatic is chaemia/reperfusion. Transpl Int 18: 604-612. [crossref]

16. León OS, Ajamieh HH, Berlanga J, Menéndez S, Viebahn-Hánsler R, et al. (2008) Ozone oxidative preconditioning is mediated by $\mathrm{A} 1$ adenosine receptors in a rat model of liver ischemia/ reperfusion. Transplant Int 21: 39-48. [crossref]

17. Ajamieh H, Merino N, Candelario-Jalil E, Menéndez S, Martinez-Sanchez G, et al. (2002) Similar protective effect of ischaemic and ozone oxidative preconditionings in liver ischaemia/reperfusion injury. Pharmacol Res 45: 333-339. [crossref]

18. Gultekin FA, Cakmak GK, Turkcu UO, Yurdakan G, Demir FE, et al. (2013) Effects of ozone oxidative preconditioning on liver regeneration after partial hepatectomy in rats. J Invest Surg 26: 242-252. [crossref]

19. Candelario-Jalil E, Mohammed-Al-Dalain S, Fernández OS, Menéndez S, PérezDavison G, et al. (2001) Oxidative preconditioning affords protection against carbon tetrachloride-induced glycogen depletion and oxidative stress in rats. J Appl Toxicol 21: 297-301. [crossref]

20. Aslaner A, Cakır T, Celik B, Doğan U, Akyüz C, et al. (2015) The protective effect of intraperitoneal medical ozone preconditioning and treatment on hepatotoxicity induced by methotrexate. Int J Clin Exp Med 8: 13303-13309. [crossref]

21. Sun W, Pei L (2012) Ozone preconditioning and exposure to ketamine attenuates hepatic inflammation in septic rats. Arch Med Sci 8: 918-923.

22. Chen H, Xing B, Liu X, Zhan B, Zhou J, et al. (2008) Ozone oxidative preconditioning protects the rat kidney from reperfusion injury: the role of nitric oxide. J Surg Res 149: 287-295. [crossref]

23. Chen H, Xing B, Liu X, Zhan B, Zhou J, et al. (2008) Ozone oxidative preconditioning inhibits inflammation and apoptosis in a rat model of renal ischemia/reperfusion injury. Eur J Pharmacol 581: 306-314. [crossref]

24. Chen H, Xing B, Liu X, Zhan B, Zhou J, et al. (2008) Similarities between ozone oxidative preconditioning and ischemic preconditioning in renal ischemia/ reperfusion injury. Arch Med Res 39: 169-178. [crossref]
25. Wang L, Chen H, Liu XH, Chen ZY, Weng XD, et al. (2014) The protective effect of ozone oxidative preconditioning against hypoxia/reoxygenation injury in rat kidney cells. Ren Fail 36: 1449-1454. [crossref]

26. Barber E, Menéndez S, León OS, Barber MO, Merino N, et al. (1999) Prevention of renal injury after induction of ozone tolerance in rats submitted to warm ischaemia. Mediators Inflamm 8: 37-41.

27. Wang L, Chen H, Liu XH, Chen ZY, Weng XD, et al. (2014) Ozone oxidative preconditioning inhibits renal fibrosis induced by ischemia and reperfusion injury in rats. Exp Ther Med 8: 1764-1768. [crossref]

28. Xing B, Chen H, Wang L, Weng X, Chen Z, et al. (2015) Ozone oxidative preconditioning protects the rat kidney from reperfusion injury via modulation of the TLR4-NF-кB pathway. Acta Cir Bras 30: 60-66. [crossref]

29. Kurtoglu T, Durmaz S, Akgullu C, Gungor H, Eryilmaz U, et al. (2015) Ozone preconditioning attenuates contrast-induced nephropathy in rats. J Surg Res 195: 604-611. [crossref]

30. Calunga-Fernández JL, Bello-Ferro M, Chaple-la-Hoz M, Barber-Gutiérrez E, Menéndez- Cepero S, et al. (2004) Ozonoterapia en la glomerulonefritis tóxica experimental por adriamicina. Rev Cubana Invest Biomed 23: 139-143.

31. Calunga JL, Zamora ZB, Borrego A, Río SD, Barber E, et al. (2005) Ozone therapy on rats submitted to subtotal nephrectomy: role of antioxidant system. Mediators Inflamm 2005: 221-227.

32. Morsy MD, Hassan WN, Zalat SI (2010) Improvement of renal oxidative stress markers after ozone administration in diabetic nephropathy in rats. Diabetol Metab Syndr 2: 29. [crossref]

33. Aslaner A, Çakır T, Çelik B, Doğan U, Mayir B, et al. (2015) Does intraperitoneal medical ozone preconditioning and treatment ameliorate the methotrexate induced nephrotoxicity in rats? Int J Clin Exp Med 8: 13811-13817. [crossref]

34. Delgado-Roche L, Hernández-Matos Y, Medina EA, Morejón DÁ, González MR, et al. (2014) Ozone-Oxidative Preconditioning Prevents Doxorubicin-induced Cardiotoxicity in Sprague-Dawley Rats. Sultan Qaboos Univ Med 14: 342-348 [crossref]

35. Ahmed LA, Salem HA, Mawsouf MN, Attia AS, Agha AM (2012) Cardioprotective effects of ozone oxidative preconditioning in an in vivo model of ischemia/ reperfusion injury in rats. Scand J Clin Lab Invest 72: 345-354. [crossref]

36. El-Sawalhi MM, Darwish HA, Mausouf MN, Shaheen AA (2013) Modulation of agerelated changes in oxidative stress markers and energy status in the rat heart and hippocampus: a significant role for ozone therapy. Cell Biochem Funct 31: 518-525. [crossref]

37. Koca K, Yurttaş Y, Yıldız C, Caycı T, Uysal B, et al. (2010) Effect of hyperbaric oxygen and ozone preconditioning on oxidative/nitrosative stress induced by tourniquet ischemia/reperfusion in rat skeletal muscle. Acta Orthop Traumatol Turc 44: 476-483. [crossref]

38. Ozkan H, Ekinci S, Uysal B, Akyildiz F, Turkkan S, et al. (2015) Evaluation and comparison of the effect of hypothermia and ozone on ischemia-reperfusion injury of skeletal muscle in rats. J Surg Res 196: 313-319. [crossref]

39. Kesik V, Uysal B, Kurt B, Kismet E, Koseoglu V (2009) Ozone ameliorates methotrexate- induced intestinal injury in rats. Cancer Biol Ther 8: 1623-1628. [crossref]

40. Bakkal BH, Gultekin FA, Guven B, Turkcu UO, Bektas S, et al. (2013) Effect of ozone oxidative preconditioning in preventing early radiation-induced lung injury in rats. Braz J Med Biol Res 46: 789-796. [crossref]

41. Rodríguez ZZ, Guanche D, Alvarez RG, Rosales FH, Alonso Y, et al. (2009) Preconditioning with ozone/oxygen mixture induces reversion of some indicators of oxidative stress and prevents organic damage in rats with fecal peritonitis. Inflamm Res 58: 371-375. [crossref]

42. Alvarez RG, Zamora ZB, Borrego A, Delgado R, Schulz S, et al. (2009) Ozone oxidative preconditioning reduces nitrite levels in blood serum in LPS: induced endotoxic shock in mice. Inflamm Res 58: 441-443. [crossref]

43. Awasthi YC, Ansari GA, Awasthi S (2005) Regulation of 4-hydroxynonenal mediated signaling by glutathione S-transferases. Methods Enzymol 401: 379-407. [crossref]

44. Poli G, Schaur RJ, Siems WG, Leonarduzzi G (2008) 4-hydroxynonenal: a membrane lipid oxidation product of medicinal interest. Med Res Rev 28: 569-631. 
45. Sagai M and Bocci V (2011) Mechanisms of Action Involved in Ozone Therapy: Is healing induced via a mild oxidative stress? Med Gas Res 1: 29.

46. Morimoto RI, Kline MP, Bimston DN, Cotto JJ (1997) The heat-shock response: regulation and function of heat-shock proteins and molecular chaperones. Essays Biochem 32: 17-29. [crossref]

47. Jolly C, Morimoto RI (2000) Role of the heat shock response and molecular chaperones in oncogenesis and cell death. J Natl Cancer Inst 92: 1564-1572. [crossref]

48. Kliková K, Pilchova I, Stefanikova A, Hatok J, Dobrota D, et al. (2016) The role of heat shock proteins in Leukemia. Klin Onkol 29: 29-38. [crossref]

49. Kiang JG, Tsokos GC (1998) Heat shock protein $70 \mathrm{kDa}$ : molecular biology, biochemistry, and physiology. Pharmacol Ther 80: 183-201. [crossref]

50. Pecorelli A, Bocci V, Acquaviva A, Belmonte G, Gardi C, et al. (2013) NRF2 activation is involved in ozonated human serum upregulation of HO-1 in endothelial cells. Toxicol Appl Pharmacol 267: 30-40. [crossref]

51. Bocci V, Valacchi G (2015) Nrf2 activation as target to implement therapeutic treatments. Front Chem 3: 4 .

52. Re L, Martínez-Sánchez G, Bordicchia M, Malcangi G, Pocognoli A, et al. (2014) Is ozone pre-conditioning effect linked to Nrf2/EpRE activation pathway in vivo? A preliminary result. Eur J Pharmacol 742: 158-162. [crossref]

53. Delgado-Roche L, Riera-Romo M, Mesta F, Hernández-Matos Y, Barrios JM, et al (2017) Medical ozone promotes Nrf2 phosphorylation reducing oxidative stress and pro-inflammatory cytokines in multiple sclerosis patients. Eur J Pharmacol 811: 148154. [crossref]

54. Valacchi G, Bocci V (2000) Studies on the biological effects of ozone: 11. Release of factors from human endothelial cells. Mediators Inflamm 9: 271-276.

55. Upchurch GR, Welch GN, Loscalzo J (1996) The vascular biology of S-nitrosothiols, nitrosated derivatives of thiols. Vasc Med 1: 25-33. [crossref]

56. Shinriki N, Suzuki T, Takama K, Fukunaga K, Ohgiya S, et al. (1998) Susceptibilities of plasma antioxidants and erythrocyte constituents to low levels of ozone. Haematologia (Budap) 29: 229-239. [crossref]

57. Bocci V (2011) Ozone: A new medical drug. Netherlands: Springer.

58. Joyner MJ, Dietz NM (1997) Nitric oxide and vasodilation in human limbs. J Appl Physiol 83: 1785-1796. [crossref]

59. Molinari F, Rimini D, Liboni W, Acharya UR, Franzini M, et al. (2017) Cerebrovascular pattern improved by ozone autohemotherapy: an entropy-based study on multiple sclerosis patients. Med Biol Eng Comput 55: 1163-1175. [crossref]

60. Pressman S y Warburg OH (2000) The story of ozone. 6th ed. San Diego: Plasmafire Intl.

61. National Library of Medicine. Pubmed - NCBI Search.

62. Verga C (1989) Nuovo approccio terapeutico alle ernie protusioni discali lombari. Riv Neuroradiol 2: 148.

63. Bocci V (2002) Oxygen-Ozone Therapy. A critical evaluation. Dordrecht, The Netherlands: Kluwer Academic Publishers.

64. Bocci V, Travagli V, Zanardi I (2009) May oxygen-ozone therapy improves cardiovascular disorders? Cardiovasc Hematol Disord Drug Targets 9: 78-85. [crossref]

65. Clavo B, Pérez JL, López L, Suárez G, Lloret M, et al. (2003) Effect of ozone therapy on muscle oxygenation. J Altern Complement Med 9: 251-256. [crossref]

66. Clavo B, Catalá L, Pérez JL, Rodríguez V, Robaina F (2004) Ozone therapy on peripheral blood flow: A preliminary report. Evid Based Complement Alternat Med 1: 315-319. [crossref]

67. Giunta R, Coppola A, Luongo C, Sammartino A, Guastafierro S, et al. (2001) Ozonized autohemotransfusion improves hemorheological parameters and oxygen delivery to tissues in patients with peripheral occlusive arterial disease. Ann Hematol 80: 745-748. [crossref]

68. Borroto RV, Lima HLB, Lima GS, Marín DME, Castellanos SJC, et al. (2013) Prevention of the stroke with the application of ozone therapy. Rev Cub Med Fis Rehab 5: 3-16.

69. Hernández F, Menéndez S, Wong R (1995) Decrease of blood cholesterol and stimulation of antioxidative response in cardiopathy patients treated with endovenous ozone therapy. Free Radic Biol Med 19: 115-119. [crossref]
70. Rodríguez MM, García JR, Menendez S, Devesa E, Valverde S (1998) Ozonoterapia en la enfermedad cerebro-vascular isquémica. Revista CENIC Ciencias Biológicas 29: 145-148.

71. Hernández Rosales FA, Calunga Fernández JL, Turrent Figueras J, Menéndez Cepero S, Montenegro Perdomo A (2005) Ozone therapy effects on biomarkers and lung function in asthma. Arch Med Res 36: 549-554. [crossref]

72. Calunga JL, Paz Y, Menendez S, Martínez A, Hernández A (2011) Rectal ozone therapy for patients with pulmonary emphysema. Rev Med Chile 139: 439-447. [crossref]

73. Borrelli E, Bocci V (2014) Oxygen ozone therapy in the treatment of chronic obstructive pulmonary disease: An integrative approach. Am J Clin Exp Med 2: 9-13.

74. Bocci V, Paulesu L (1990) Studies on the biological effects of ozone 1. Induction of interferon gamma on human leucocytes. Haematologica 75: 510-515 [crossref]

75. Bocci V, Valacchi G, Corradeschi F, Aldinucci C, Silvestri S, et al. (1998) Studies on the biological effects of ozone: 7. Generation of reactive oxygen species (ROS) after exposure of human blood to ozone. J Biol Regul Homeost Agents 12: 67-75. [crossref]

76. Larini A, Bocci V (2005) Effects of ozone on isolated peripheral blood mononuclear cells. Toxicol In Vitro 19: 55-61. [crossref]

77. Diaz-Luis J, Menendez-Cepero S, Macias-Abraham C (2015) Ozone therapy immunomodulatory effect in the selective immunoglobulin A deficiency. J Ozone Ther 1: 2-9.

78. Puga R, Rodrigues R, Gonzales C, Munoz J (1997) Ozone therapy in treatment of patients with secondary mmunodeficiencies. In: CENIC. 2nd International Symposium on Ozone Applications, Havana, Cuba: CNIC; 1997: 54-55.

79. D'Ambrosio CM (2002) Trattamento delle malattie infiammatorie croniche dell'intestino mediante ossigeno-ozonoterapia, Riv. Ital. Ossigeno Ozonoterapia 1: 155-158.

80. D'Ambrosio CM (2002) Terapia delle IBD mediante ozonoterapia per via rettale, Riv. Ital. Ossigeno Ozonoterapia 1: 159-163.

81. Menendez F, Díaz G, Menendez S (1989) [Ozone therapy in rheumatoid arthritis]. Rev CENIC Cienc Biol 20: 144-151.

82. Esperanza, S., Ortellado, M (2011) [Ozone therapy in the treatment of rheumatoid arthritis, monitoring and evolution from September 2006-April 2011]. In: ABOZ. III Iberoamerican Congress of Ozonetherapy. II. Brazilian Congress of Ozonetherapy. I. Brazilian Congress of Hydro-Ozonetherapy, Rio de Janeiro: ABOZ.

83. Vinnik IS, Salmina AB, Tepliakova OV, Drobushevskaia AI, Pozhilenkova EA, et al. (2015) [The results of combined ozone therapy using in complex treatment of soft tissues infections in patients with diabetes mellitus type II]. Khirurgiia (Mosk) 2015: 63-69.

84. Niu T, Lv C, Yi G, Tang H, Gong C, et al. (2018) Therapeutic effect of medical ozone on lumbar disc herniation. Med Sci Monit 24: 1962-1969. [crossref]

85. Lin SY, Zhang SZ, An JX, Qian XY, Gao XY, et al. (2018) The effect of ultrasoundguided percutaneous ozone injection around cervical dorsal root ganglion in zosterassociated pain: a retrospective study. J Pain Res 11: 2179- 2188. [crossref]

86. Wang X, He P, Zhou Z, Ouyang X (2013) Curative analysis of pregabalin combined with medical ozone in treating old patients with postherpetic neuralgia. J Mod Med Health 10: 1475-1478.

87. Wang L, Zhang Z (2016) Therapeutic observation of acupuncture plus ozone injection for neuralgia due to acute Herpes Zoster. Shanghai J Acup Moxib 35: 527-529.

88. Yang M (2011) Clinical observation on efficacy of ozone combined with epidural anesthesia in treatment of Herpes Zoster neuralgia. J Xianning University 2: 110-112.

89. Jiang L, Li Y (2017) Clinical observation of treating PHN by dorsal root ganglia radio frequency combined ozone. J Med Res 46: 138-142.

90. An JX, Liu H, Chen RW, Wang Y, Zhao WX, et al. (2018) Computed tomographyguided percutaneous ozone injection of the Gasserian ganglion for the treatment of trigeminal neuralgia. J Pain Res 11: 255-263. [crossref]

91. Kumar T, Arora N, Puri G, Aravinda K, Dixit A, et al. (2016) Efficacy of ozonized olive oil in the management of oral lesions and conditions: A clinical trial. Contemp Clin Dent 7: 51-54. [crossref]

92. Pereira J, Sargento P, Faria M, Teixeira M (2017) Ozone therapy for Herpes Zoster: case report. In: Ribeiro J, Lima E. Book of minutes of the II National Meeting of New Health Researchers \& II International Meeting of New Health. Leiria: Politécnico de Leiria; 2017. 
93. Huang J, Huang J, Xiang Y, Gao L, Pan Y, et al. (2018) [Topical ozone therapy: An innovative solution to patients with herper zoster]. Zhong Nan Da Xue Xue Bao Yi Xue Ban 43: 168- 172. [crossref]

94. Mandzhgaladze NR, Kharebava ER, Didia TsG, Ardzhevanishvili MD, Gudzhabidze $\mathrm{MV}$, et al. (2006) [Influence of intravenous ozone treatment on the level of different specificity antibodies]. Georgian Med News 138: 93-5. [crossref]

95. Hu B, Zheng J, Liu Q, Yang Y, Zhang Y (2018) The effect and safety of ozone autohemotherapy combined with pharmacological therapy in postherpetic neuralgia. J Pain Res 11: 1637- 1643. [crossref]

96. Carpendale MT, Freeberg JK (1991) Ozone inactivates HIV at noncytotoxic concentrations. Antiviral Res 16: 281-92.

97. Bocci V (1994) A reasonable approach for the treatment of HIV infection in the early phase with ozonetherapy (autohaemotherapy). How 'Inflammatory' cytokines may have a therapeutic role. Mediators Inflamm 3: 315-321. [crossref]

98. Bocci V, Venturi G, Catucci M, Valensin PE, Zazzi M (1998) Lack of efficacy of ozone therapy in HIV infection. Clin Microbiol Infect 4: 667-669. [crossref]

99. Garber GE, Cameron DW, Hawley-Foss N, Greenway D, Shannon ME (1991) The use of ozone- treated blood in the therapy of HIV infection and immune disease: a pilot study of safety and efficacy. AIDS 5: 981-984. [crossref]

100. Carpendale MT, Freeberg J, Griffiss JM (1993) Does ozone alleviate AIDS diarrhea? J Clin Gastroenterol 17: 142-145.
101. Cespedes-Suarez J, Martin-Serrano Y, Carballosa-Peña MR, Dager- Carballosa DR (2018) The immune response behavior in HIV-AIDS patients treated with Ozone therapy for two years. J Ozone Ther 2: 1-9.

102. Neronov VA (2009) [Experience with the use of ozone for the treatment of chronic viral hepatitis]. Vopr Kurortol Fizioter Lech Fiz Kult 6: 14-17. [crossref]

103. Chernyshev AL, Filimonov RM, Karasev AV, Neronov VA, Maksimov VA (2008) [Combined treatment including ozonetherapy of patients with viral hepatitis]. Vopr Kurortol Fizioter Lech Fiz Kult 3: 19-22. [crossref]

104. Jiao XJ, Peng X (2008) [Clinilal study of medical ozone therapy in chronic hepatitis B of 20 patients]. Zhonghua Shi Yan He Lin Chuang Bing Du Xue Za Zhi 22: 484-485. [crossref]

105. Cespedes-Suarez J, Martin-Serrano Y, Carballosa-Peña MR, Dager-Carballosa DR (2018) Response of patients with chronic Hepatitis B in one year of treatment with Major Autohemotherapy. J Ozone Ther 2: 1-7.

106. Zaky S, Kamel SE, Hassan MS, Sallam NA, Shahata MA, et al. (2011) Preliminary results of ozone therapy as a possible treatment for patients with chronic hepatitis C. J Altern Complement Med 17: 259-263. [crossref]

107. Gu XB, Yang XJ, Zhu HY, Xu YQ, Liu XY (2010) Effect of medical ozone therapy on renal blood flow and renal function of patients with chronic severe hepatitis. Chin Med J (Engl) 123: 2510-2513.

108. Menendez-Cepero S, Zamora Z, Hernandez F (2018) Importance of the toxicological tests in the application and safety of ozone therapy. J Ozone Ther 2018: 2.

109. Menéndez S, Weisser M (2016) Advances of Ozone Therapy in Medicine \& Dentistry. Havanna: Havanna University 2016.

\section{Citation:}

Hidalgo Tallón FJ, Menendez-Cepero S, Baeza-Noci J, Carrasco GG (2021) Theoretical Basements for a Clinical Trial on COVID-19 Patients with Systemic Ozone Therapy.. J Neurol Neurocrit Care Volume 4(1): 1-6. 